\title{
THE RELATIONSHIP BETWEEN HBSAG AND HBV DNA IN HBVINFECTED BLOOD DONORS
}

\author{
Zohreh, Sharifi ${ }^{1}{ }^{*}$, Mahmoud Mahmoudian Shooshtari ${ }^{1}$ \\ 1Assistant professor of Research center, Iranian Blood Transfusion Organization (IBTO), Tehran, Iran.
}

\begin{abstract}
Hepatitis B virus (HBV) screening among blood donors in Iran is focused on the presence of hepatitis B surface antigen (HBsAg). The absence of HBsAg in the healthy blood donors may not be sufficient to ensure lack of circulating HBV. However, nucleic acid testing (NAT) has been introduced in most developed countries for the screening of infectious agents in pooled plasma and individual donation. Understanding the relationship between $\mathrm{HBs} A g$ and HBV deoxyribonucleic acid (DNA) concentrations in HBV infected blood donor is an important in assessing the roles that HBsAg assays and HBV NAT will play in the future of blood screening. The aim of this study was to show the results about screening for HBV in blood donors and to remark the relationship between HBV DNA and HBsAg.

HBsAg testing for 58400 healthy volunteer donors was conducted using HBsAg Enzyme Immunoassay kit (Monolisa, Bio-RAD, France) during Sep2004 to Feb 2005. All specimens repeatedly reactivate for $\mathrm{HBsAg}$ were tested and confirmed by a neutralization assay $(\mathrm{HBs} A \mathrm{~g}$ confirmatory assay Monolisa, Bio-RAD, France). Samples from HBsAg positive donations were tested using semi-nested PCR to detect HBV DNA. A total of $350(0.6 \%)$ of 58400 blood donors were HBsAg positive. HBV DNA was detected among 90 of $350(25.7 \%)$ of the HBsAg positive blood donors. HBV DNA was not found among $260(74.2 \%)$ of the positive HBsAg donors.HBV DNA levels in HBsAg positive blood donations can be extremely low. About 74.2 percent of donations would remain undetected by single donor NAT. These results indicate that HBsAg positive units from donors in the chronic stage of infection or late infection may contain very low or intermittently detectable DNA levels that single sample NAT would miss.
\end{abstract}

Keywords: • HBV-DNA • NAT • HBsAg • Blood donors.

\section{Introduction}

$\mathrm{H}$ epatitis B is a major global public health problem. According to World Health Organization (WHO) statistics, 2 billion people have been infected with the HBV worldwide, 350 million currently have chronic infections, and 4 million new acute clinical cases occur annually $(1,2)$. One million carriers die each year from chronic active hepatitis, cirrhosis, or primary liver cancer. HBV is transmitted by exposure to infected blood or body fluids with most infectious agents occurring through sexual contact with infected persons, intravenous drug abuse, transfusion of unscreened infectious blood or blood products, or perinatally. Improvements in serologic screening assays along with increasingly

*Corresponding author: Hoorieh Soleimanjahi, Department of Virology, Faculty of Medical Sciences, Tarbiat Modares University, Tehran, Iran. Fax: +98-21-88013030, Tel: +98-2188011001 ext 3561. E-mail: Soleim h@modares.ac.ir stringent donor selection and the use of the hepatitis B vaccine have vastly reduced the risk of HBV transmission from transfused blood or blood products. However, in spite of these measures, there remains a residual risk of transmitting HBV through transfusion of infected blood or blood components. With the successful implementation of pooled-sample NAT for human immunodeficiency virus (HIV) and hepatitis C virus $(\mathrm{HCV})$ in many developed countries $(3,4)$, there is understandable interest in the potential benefit of HBV NAT in donor screening.

Understanding the relationship between $\mathrm{HBsAg}$ and HBV DNA concentrations in HBV infected blood donors is important in assessing the roles that HBsAg assays and HBV NAT will play in the future of blood screening(5). Comparisons of serum HBsAg levels and sensitivity of the HBsAg assay with HBV NAT detection limits have focused primarily on evaluation of hepatitis $\mathrm{B}$ seroconversion series during the early window period of acute infection (5). The linear 


\section{Hooreih Soleimanjahi et. al}

relationship between $\mathrm{HBsAg}$ assay values and HBV DNA levels exists only during early seroconversion (6). The relationship between HBsAg and HBV DNA level is clearly not correlated during late infection or during chronic infection (6). Thus, the utility of associating a viral load value with an HBsAg concentration is limited, since it is not representative of the relationship between HBV DNA and HBsAg in the vast majority of HBV-positive sample that are tested in blood screening or in the diagnostic setting $(7,8)$.

Each country will need to develop its blood screening strategy based on HBV endemicity; yields of infectious units detected by different serologic/NAT screening methods, and cost effectiveness of test methods in ensuring blood safety. The key questions regarding NAT for HBV include: 1) can NAT replace HBsAg screening of blood donors? 2) Can NAT replace anti-HBc testing of blood donors? The purpose of this study was to show the results about screening for HBV in blood donors and to remark the relationship between HBV DNA and HBsAg.

\section{Materials and Methods}

Serum specimens. Whole blood samples were collected randomly from 58400 healthy volunteer blood donors, who were referred to blood transfusion center, Tehran, Iran during September 2004 to February2005. Donors were interviewed and medically examined before blood donation. Those with high-risk behaviour including intravenous drugs abusers or with any medical problems were excluded from the study population.

At the time of the blood donation, routine HBsAg testing was conducted by Enzyme Immunoassay kit (Monolisa, Bio-RAD, France). All specimens in this study were repeatedly reactive by $\mathrm{HBsAg}$ Enzyme Immunoassay kit and confirmed by the confirmatory assay (Monolisa, Bio-RAD, France). Other screening test such as anti human immunodeficiency virus (HIV), anti hepatitis C virus (HCV), serologic tests for syphilis (STS) followed by routine blood banking procedures were carried out for each individual donor. Then, samples from HBsAg positive donations were tested using semi-nested PCR to detect HBV DNA. DNA extraction. HBV DNA was extracted from $100 \mu \mathrm{l}$ of serum by the proteinase K-sodium dodecyle sulfate lysis and phenol-chloroform extraction methods as described previously $(9,10)$.
Serum was mixed with $300 \mu$ of Tris hydrochloride buffer (13.3 mM, pH 8) containing $6.7 \mathrm{mM}$ EDTA, $0.67 \% \quad(\mathrm{wt} / \mathrm{vol}) \quad$ SDS, and proteinase $\mathrm{K}(133 \mu \mathrm{g} / \mathrm{ml})$ and incubated at $70{ }^{\circ} \mathrm{C}$ for $3 \mathrm{~h}$. The suspension was sequentially extracted with phenol and then with chloroform. The DNA was precipitated with $0.3 \mathrm{M}$ sodium acetate and then with absolute ethanol, washed with $70 \%$ ethanol, vacuum dried, and then dissolved in a final volume of $30 \mu \mathrm{l}$ of sterile, and nuclease-free water.

PCR amplification. Extracted DNA was amplified by semi-nested PCR with outer primers (sense primer, 5' YCCTGTGGTGGCTCCAGTTC 3'; atisense primer, 5 AAGCCANACARTGGGGGAAAGC $3^{\prime}$ ) (11), followed by second -round PCR with primers specific for the pre-S1/pre-S2 region of HBV (sense primer, 5GTCTAGACTCGTGGTGG ACTTCTCTC'3 '; antisense primer, 5'AAGCCANACA RTGGGGGAAAGC 3') (11). The assay was performed according to the standard PCR assay (11). Five microlitre of DNA extract or the first-round PCR product was added to $45 \mu 1$ of reaction mixture containing $0.3 \mu \mathrm{L}$ of $5 \mathrm{U} / \mu \mathrm{L}$ Taq DNA polymerase, $1 \mu \mathrm{l}$ of $10 \mathrm{Pico} \mathrm{mol} / \mu \mathrm{l}$ of each primer, $200 \mu \mathrm{m}$ of each deoxynucleotid triphosphate, $5 \mu \mathrm{l}$ of reaction buffer $(50 \mathrm{mM} \mathrm{KCl}$, $10 \mathrm{mM}$ Tris - $\mathrm{HCl}, \mathrm{pH}=8.3$ ) and $1.5 \mathrm{mM} \mathrm{MgCl} 2$. Samples were denatured for $5 \mathrm{~min}$ at $94^{\circ} \mathrm{C}$ and then subjected to 40 cycles of $1 \mathrm{~min}$ at $94^{\circ} \mathrm{C}, 1 \mathrm{~min}$ at $58^{\circ} \mathrm{C}$ and $1 \mathrm{~min}$ at $72^{\circ} \mathrm{C}$ in a thermal cycler (Techne, England).

Detection of PCR product. Ten $\mu 1$ of reaction product was electrophoresed in a $2 \%$ agarose gel made in Tris-acetated-EDTA (TAE) buffer, $\mathrm{pH}=8$ 8.5 and visualized by UV illumination after ethidium bromide $(10 \mu \mathrm{g} / \mathrm{ml})$ staining. Positive and negative controls were also treated as samples.

Determination of the sensitivity of PCR. Sensitivity of the standard PCR assay were evaluated using serial dilutions of the international reference standard, Europe genotypes A, C, D, E. Conventional gel electrophoresis and ethidium bromide staining were then used to analyze the PCR amplification products from these templates. Statistical analysis: The SPSS software version 11.5, chi-square test was used to analyze the data.

\section{Results}

A total of $350(0.6 \%)$ of 58400 blood donors were HBsAg positive. Thus, 58050 of blood donors were negative for HBsAg. 
HBV DNA was determined by a qualititative HBV DNA PCR assay.

The assay performed according to the standard PCR assay. The limit of detection of genotypes A, $\mathrm{C}, \mathrm{D}$, and E was $3000 \mathrm{HBV}$ DNA copies per $\mathrm{ml}$.

A total of 350 of the HBsAg positive blood donors were tested for HBV DNA. HBV DNA was detected among 90 of 350 (25.7\%) HBsAg positive specimens. In 90 (25.7\%) of the HBsAg positive blood donor HBV DNA was repeatedly detected, and $260(74.2 \%)$ of the HBsAg positive blood donors HBV DNA was not found. The HBV DNA in 90 specimens was amplified by $\mathrm{S}$ gene specific primers. The PCR products were visualized on a $2 \%$ agarose gel stained with ethidium bromide. Table 1 shows finding from this study that included data on detection of HBV DNA in confirmed HBsAg-positive donors. The PCR products with 475 base pair length obtained with both set of primers is shown in figure.1. An association was not seen between the OD HBsAg positive and the intensity of expected PCR product band, after electrophoresis and ethidium bromide staining.

Table1. Prevalence of HBV DNA in HBsAg positive blood donors.

\begin{tabular}{lll}
\hline $\begin{array}{l}\text { HBsAg positive } \\
\text { Negative }\end{array}$ & HBV DNA Positive & HBV DNA \\
& n o $(\%)$ & n o $\quad(\%)$ \\
\hline 350 & $90(25.7 \%)$ & $260(74.2 \%)$ \\
\hline
\end{tabular}

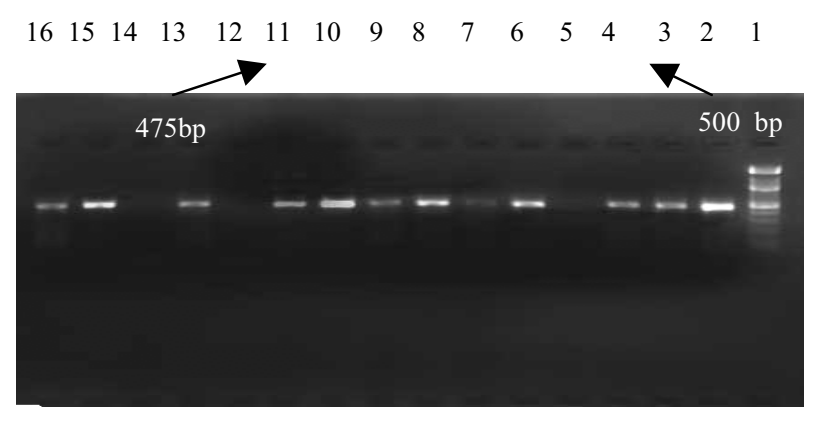

Fig.1. Agarose gel electrophoresis of semi-nested PCR products of HBV $S$ gene DNA in HBsAg positive blood donors. Lane1 DNA size Marker (100 bp ladder Fermentas). Lane 14 negative control sample using Viral Quality Control (VQC) panel negative serum (BBL). Lanes 15, 16 PCR products with 475 base pair length generated using $S$ gene specific primers of hepatitis $B$ virus using VQC panel serum (BBL) (positive control). Lanes 2-13 PCR products of HBsAg positive blood donors using $S$ gene specific primers.

\section{Discussion}

Previous investigations have shown a significant positive correlation between HBV DNA concentrations and HBsAg levels during the viral ramp-up phase of acute infection when $\mathrm{HBsAg}$ and HBV DNA levels rapidly increase in a linear and proportionate fashion $(12,13)$. The ramp-up phase is a period during which DNA could be quantified and viral load was seen to increase progressively over time as opposed to the before ramp-up phase where low level HBV DNA is intermittently detected only higher sensitivity qualitative PCR or other NAT assays (13). The after ramp-up phase is the period after HBsAg becomes reactive and viral load progression is either showed or stopped. In addition, Biswas et al (2003) showed that detection rates and window period differences varied between HBsAg and NAT assays during the rampup phase of seroconversion (12). Seroconversion donors are not the only source of risk for post transfusion hepatitis but recent reports indicate that HBV may be present in donations from chronic HBV carries who have undetectable HBsAg but are positive for anti hepatitis B core antigen $(\mathrm{HBc})$ $(14,15)$. Kuhn's et al examined whether NAT can replace HBsAg screening of blood donors. In their studies, samples from $200 \mathrm{HBsAg}$ and anti-HBc positive donations were tested using 3 PCR assays. They found a poor correlation between HBsAg titer and serum HBV DNA levels. In Kuhn's et al (2004) report, only $64 \%$ of the samples had detectable HBV DNA using a commercially available PCR assay with detection limit of 400 copies $/ \mathrm{ml}, 30 \%$ had detectable HBV DNA by an assay with detection limit of 65 copies $/ \mathrm{ml}, 3 \%$ had detectable HBV DNA by an assay with detection limit of 1.3 copies $/ \mathrm{ml}$, while $3 \%$ had undetectable HBV DNA even with the most sensitive assays (5). In a Japanese study, of 59 low-level HBsAgpositive donor samples with complete PCR results, 25 had DNA concentrations $<100$ copies/ml (12). These donors were followed for more than a year and classified as having chronic HBV infection. Interestingly, most of these infectious agents were not detectable by PCR with surface antigen gene primers but required core region primers and a 1 $\mathrm{ml}$ sample input volume. Two other HBsAg positive donors from that same study, also classified as chronic carriers, were PCR negative even with a $1 \mathrm{ml}$ sample input volume(12).

In two studies performed in United State, 3\% $(6 / 200)$ to $6 \%(6 / 99)$ of HBsAg-positive donors 
had HBV DNA level $<$ or $=100$ copies $/ \mathrm{ml}$ and another 3-6\% were HBV NAT negative using highly sensitive NAT assay with $95 \%$ detection limits of 6-60 HBV DNA copies/ml (16).

Like other results, in this present study HBV DNA was not found in $260(74.2 \%)$ of the HBsAg positive blood donors. (The limit of detection 3000 HBV DNA copies per $\mathrm{ml}$ ). These results show that some HBsAg-positive blood donors in the chronic stage of infection have very low or intermittently detectable HBV DNA levels and would not be identified by single sample NAT methods.

Prevention of transfusion transmitted HBV has historically relied on serologic screening of blood and plasma donations for HBsAg. In addition to screening of blood donations for HBsAg, some countries also screen for anti-HBc to detect anti-HBc reactive chronic carries with low-level viremia that lack detectable HBsAg. NAT for HBV DNA was introduced in a few blood centers in Europe, as well as throughout Japan, to identify HBV infected units during the early phase of acute infection before $\mathrm{HBsAg}$ or anti $-\mathrm{HBc}$ is detectable, and in chronic carriers with undetectable levels of HBsAg (particularly in cases where anti- HBc testing is not performed).

In Iran that blood donors do not routinely screen for anti- $\mathrm{HBc}, \mathrm{HBsAg}$ testing is the only means of detection from chronically infected individuals with low/intermittently detectable DNA, since even single-donor NAT would not identify these potentially infectious blood units.

However, the results show that HBV DNA is not detectable in a subset of $\mathrm{HBsAg}$ positive donations, raising concern about the safety impact of replacing HBsAg with HBV NAT, particularly in the absence of anti HBc screening.

In conclusions, this study shows that HBV DNA level during the chronic stages of HBV infection is low and that serologic screening rather NAT screening, may be more effective for the detection of chronic carriers.

\section{References}

1 World Health Organization. Hepatitis B [online]. Available from URL; http//www,who.int/csr/disease/ hepatitise/ whocdscsrlyo 20022/en/index1.html [Accessed 2005 Sep 13]

2 Chu CJ, Keeff EB, Han SH, Perrillo RP, et al. Hepatitis $B$ virus Genotypes in the United States results of a nationwide study. Gastroenterology.2003; 125:444451.

3 AllainJ-p. Occult hepatitis part I: the discovery, diagnostic tests, and new viruses. Lab Med 1995; 26(10) L: 650-9.
4 Stramer SL, Glynn SA, Kleinman SH, et al. Detection of $\mathrm{HIV}$ and $\mathrm{HCV}$ infections among antibody-negative blood donor by nucleic-amplification testing Engl J Med 2004; 351(8): 760-8.

5 Kuhn's MC, Kleinman SH, McNamara AL, et al. Lack of correlation between HBsAg and HBV DNA levels in blood donors who test positive for HBsAg and anti-HBc: implications for future HBV screening policy. Transfusion 2004; 44:1332-9.

6 Kuhns M. C. and Busch M.P. New strategies for blood donor screening for Hepatitis B Virus.Mol Dia.2006; 10(2):77-91.

7 Hennig H, Puchta I, Luhm J, et al. Frequency and load of hepatitis B virus DNA in first time blood donors with antibodies to hepatitis B core antigen.Blood.2002; 100:2637-41.

8 Roth WK, weber M, Petersen D, et al. NAT for HBV and anti $\mathrm{HBc}$ testing increase blood safety. Transfusion. 2002; 42:863-75.

9 Heermann KH, Gerlich W H, Chudy M, Schaefer S. Quantitative detection of hepatitis B virus DNA in two international reference plasma preparations. J Clin Mic. 1999; 37(1): 68-73.

10 Janssen HL, Vanzonneveld M, Senturk H, Zeuzem S, et al. Pegylated interferon alfa- $2 \mathrm{~b}$ alon or in combination with Lamivudine for HbeAg-positive chronic hepatitis B:a randomized trial.Lancet.2005;36:123-129.

11 Mizokami M, Nakano T, Orito E, Tanaka Y, Sakugawa H, Mukaide M, Robertson BH. Hepatitis B virus genotype assignment using restriction fragment length polymorphism patterns. FEBS Lett.(1999); 45: 66-71.

12 Sato S, Ohhashi W, Ihara $\mathrm{H}$, et al. Comparison of the sensitivity of NAT using pooled donor samples for HBV and that of a serologic HBsAg assay.Transfusion.2001; 41:1107-13.

13 Biswas R, Tabor E, Hsiac C, et al. Comparative sensitivity of HBV NATs and HBsAg assay $s$ for detection of acute HBV infection. Transfusion. 2003; 43:788-980

14 Kleinman SH, Kuhns MC, Todd DS, et al. Frequency of HBV DNA detection in us blood donors testing positive for the presence of anti $\mathrm{HBc}$ : implications for transfusion transmission and donor screening. Transfusion .2003; 43:696-704.

15 Allain IP, Hewitt PE, Tedder RS, Williamson LM. Evidence that anti-HBc but not HBV DNA testing may prevent some HBV transmission by transfusion. $\mathrm{Br}$ Jhematol.1999; 107:186-95.

16 Kleinman SH, Strong DM, Tegtmeier GG, et al. Hepatitis B Virus (HBV) DNA screening of blood donation in minipools with the COBAS Ampliscreen HBV test. Transfusion 2005.45:1247-57.

17 kuhns MC, McNamara AL, Peterson B et al. Detection of hepatitis B seroconversion by highly sensitivitie assay for surface antigen and HBV DNA. Transfusion.1998; 38suppl.10:91s.

18 Stramer SL, Brodsky JP, Preston SB,et al. Comparative sensitivity of HBsAg and HBV NAT . Transfusion.2001; 41 suppl, 9s:8s.

19 Yoshikawa A, Gotanda $Y$, Itabashi $M$ et al. Hepatitis B NAT virus-positive blood donors in the early and late stages of HBV infection: analysis of the window period and kinetics of HBV DNA. Vox Sang.2005; 88:77-86. 